\title{
8.8 Активізація пізнавальної діяльності учнів у навчальному процесі: елементи для успішного вивчення іноземної мови
}

\section{Прийоми та методи активізації пізнавальної діяльності учнів у процесі іншомовної освіти}

Важливу роль у якісній іншомовній освіті відіграє інтерес учнів до вивчення предмету, який залежить від того, наскільки здобувач освіти усвідомлює значення матеріалу, що вивчається, а поставлені завдання безпосередньо пов’язані з його пізнавальною діяльністю.

Національна доктрина розвитку освіти в Україні [636], Національна стратегія розвитку освіти в Україні на період до 2021 року [637], Закон України «Про освіту» [638] та Концепція «Нова українська школа» [639] спрямовують педагогічну науку на пошук нових принципів та критеріїв вибору змісту освіти, нових технологій навчання, орієнтованих на розвиток особистості учня.

Нове покоління Державного стандарту базової середньої освіти визначає, що метою мовно-літературної освітньої галузі є, зокрема, розвиток компетентних мовців і читачів із гуманістичним світоглядом, які здатні спілкуватися іноземними мовами для духовного, культурного та національного самовираження та міжкультурного діалогу, для збагачення емоційно-чуттєвого досвіду, творчої самореалізації, формування ціннісних орієнтацій і ставлень [640]. Компетентнісний потенціал (здатність спілкуватися іноземними мовами як ключова компетентність) зазначеної галузі передбачає набуття учнями необхідних умінь (використовувати власний мовленнєвий досвід для вивчення іноземних мов; пояснювати роль/значення мовних явищ та системи понять, за допомогою яких формується картина світу носіїв іноземної мови; використовувати у разі потреби різноманітні стратегії для задоволення власних іншомовних комунікативних намірів; використовувати іноземні мови для розширення читацького досвіду, читацьких інтересів) та ставлень (готовність до міжкультурного діалогу; розуміння важливості оволодіння іноземними мовами для міжкультурного спілкування; 
відкритість до вивчення іноземних мов; готовність спілкуватися іноземними мовами; дотримання культури спілкування, прийнятої в сучасному суспільстві; повага до культурних та особистісних відмінностей співрозмовників; усвідомлення та урахування переваг та/або обмежень окремих груп чи осіб; виявлення розуміння і співпереживання, толерантність до представників іншого народу, носіїв іншої мови, культури, звичаїв і способу життя; розуміння потреби популяризації України у світі засобами іноземних мов) [там же].

Базові знання з іноземних мов передбачають оволодіння учнями: знання світу (значення іноземної мови для життя в мультилінгвальному та полікультурному світовому просторі; місця, установи, організації, люди, об'єкти та їх взаємозв'язок i процеси у відповідних ситуаціях спілкування); соціокультурних знань (суспільство та культура країни мови, яку вивчають) (повсякденне життя; умови життя; міжособистісні стосунки; цінності, переконання, ставлення до національної ідентичності, історії, традицій, мистецтва тощо; мова тіла; соціальні звички/умовності/стереотипи (пунктуальність, одяг, харчування, поведінка, звичаї, святкування тощо); інформацією (джерела та види інформації; достовірність та новизна інформації; критерії добору і способи пошуку інформації; явна і прихована інформація); комунікацією (комунікативна взаємодія; мета та ситуація спілкування; комунікативний намір; вербальні та невербальні засоби; типові стратегії спілкування; інтонаційні засоби; емоційний стан; формули мовленнєвого етикету; різноманітні стратегії продукування ідей; суспільно-культурний контекст комунікації; типові стратегії взаємодії; цифрове середовище; безпечна поведінка в цифровому просторі; соціально значущі запитання; онлайн-взаємодія); мовленнєвими функціями та мовними засобами (опис; розповідь; характеристика; аргументація власного вибору, погляду; запитування і надання інформації; розпитування для роз'яснення та уточнення інформації; пропонування, прийняття, відхилення пропозиції; прохання про допомогу; оцінювання подій, ситуацій, вчинків, дій, фактів; порівнювання подій, фактів, явищ; привертання уваги співрозмовника; висловлювання власних вражень, почуттів, емоцій, переконань, думок, згоди або незгоди; значення мовних явищ та іншої системи понять, за 
допомогою якої сприймається дійсність; лексичний діапазон відповідно до тематики ситуативного спілкування) [там же].

У час радикальних змін у суспільстві, реформування вітчизняної системи освіти роль педагога, його відповідальність у становленні майбутньої особистості зростає подвійно, набуває великого значення. Людина розвивається та накопичує життєвий, а також професійний досвід лише у процесі своєї діяльності, внаслідок отриманих знань та пізнань. Для того, щоб ця пізнавальна діяльність була активною та плідною, щоб приносила радість відкриттів i душевне задоволення здобувачам освіти, віру у свої сили та здібності, завдання педагога й полягає у тому, щоб допомогти учням на всіх етапах навчання активно включитися у процес освіти та самоосвіти, виявити та розкрити індивідуальні особливості та здібності кожного учня, допомогти відбутися у професії та працювати над тим, щоб випускник Нової української школи відповідав умовам та вимогам сучасного життя, був конкурентоздатним у 21-му столітті [639].

Залучення учнів до навчального процесу шляхом активізації їхньої пізнавальної діяльності - це головний шлях підвищення ефективності навчання. Психологи (Б. Ананьєв, В. Крутецький, П. Кудрявцев, Н. Менчинська, С. Рубінштейн) зробили висновок, що всі здібності людини розвиваються i вдосконалюються у ії діяльності. Перш за все, йдеться про організацію повсякденної діяльності учнів, про їі активізацію. Досвідчений педагог завжди знайде оптимальні прийоми та ефективні методи, поєднання яких дає результат у потрібному напрямку.

Ставлячи за мету розвиток пізнавальних творчих здібностей учнів, необхідно добре продумати засоби досягнення цієї мети, тверезо оцінити наявні можливості та здібності кожного учня, пред’являти адекватні вимоги для того, щоб не підірвати у них віру у власні сили, не дати в собі розчаруватися. Активізація пізнавальної діяльності - процес складний, багатогранний, що відбувається через сприйняття, відчуття, мислення здобувача освіти. Особливу роль тут відіграє мислення, оскільки всі ці процеси проходять в першу чергу через мислення або йдуть паралельно. Тому, впливаючи на мислення, учитель задіює весь ланцюжок перерахованих почуттів у відповідь на його вплив. 
Активізуючи пізнавальну діяльність учнів, педагог формує у них мотив учіння, бажання розвиватися, вдосконалюватися. Але мотиви можуть бути різні: навчання заради майбутньої улюбленої професії, почуття обов'язку перед батьками, бажання отримати високу оцінку тощо. Але найважливішим серед них $є$ інтерес до предмета. Якщо вчителю вдалося його досягти, то така важка праця, як пізнання, для учня стає доступною, захоплюючою і поступово переростає у високу якість, як допитливість. Допитливого учня у класі можна побачити відразу: він активний, постійно дискутує, готовий відповідати, вдома читає багато додаткової літератури з предмета. Завдання педагога - підживлювати цей інтерес. Тільки тоді можна говорити, що в учня склався стійкий інтерес до предмета, виник потяг до набуття знань, до пошуку шляхів самовдосконалення.

Науковці стверджують (I. Кондратюк [641], В. Краснопольський [642], Л. Ричкова [643], С. Рябчинська [644], Е. Шевченко [645]), що навчання проходить ефективніше, якщо учень відчуває інтерес до того, що вивчає, тобто виявляє пізнавальну активність. Більше того, активізація пізнавальної діяльності - це один із головних шляхів підвищення ефективності будь-якого навчання. Стимулювати пізнавальну активність здобувачів освіти - це знайти ключик, який допоможе розкрити і мобілізувати здібності кожного повною мірою, що неможливо зробити за умов традиційного репродуктивного навчання.

Умілий педагог завжди знайде необхідні засоби - методи та прийоми, для збудження й активізації пізнавальної діяльності учнів. Це й використання різних видів самостійних робіт, вирішення ситуаційних вправ, виконання індивідуальних завдань, лабораторних робіт, тестів, підготовка повідомлень і доповідей тощо. Важливу роль, якщо не основну, в активізації пізнавальної діяльності учнів відіграє й особистість учителя, його професіоналізм, ерудиція, захопленість предметом, вміння чітко та послідовно викладати матеріал, правильно ставити цілі уроку, формулювати правильно питання, уміння захоплювати учнів радістю пізнання, педагогічний такт, уміння підтримати своїх вихованців, вірити в їхній успіх. 
Прийоми та методи активізації пізнавальної діяльності різноманітні. Але їх об’єднує одне - вони передбачають поступовий і планомірний розвиток мислення учнів та одночасне формування у них мотивів учіння.

Як зауважує М. Фіцула, методи навчання слід відрізняти від методів учіння.

Методи навчання - це впорядковані способи взаємозв'язаної діяльності вчителя й учнів, направлені на досягнення мети освіти.

Метод учіння - спосіб пізнавальної діяльності учнів, зорієнтований на творче оволодіння знаннями, уміннями і навичками та вироблення світоглядних переконань на заняттях і під час самостійної роботи [646, с. 152].

Щоб розкрити поняття методу докладніше, О. Ортинський пропонує розглянути його на рівні прийомів - конкретних способів організації діяльності учня. Тоді метод навчання, як і метод виховання, стає «інструментом дотику до особистості» (А. С. Макаренко), способом спонукання й регулювання розвивальної діяльності здобувачів освіти [647, с. 185-186].

В. Гладуш та Г. Лисенко дають таке визначення: «Прийоми навчання - це складова методу, конкретні дії педагога й учнів, спрямовані на реалізацію вимог тих чи інших методів» [648, с. 88$]$.

Прийом, не маючи самостійного навчального завдання, підкоряється тому завданню, яке виконується певним методом. Але залежно від конкретних обставин кожен метод може стати прийомом або реалізуватися у своєрідних поєднаннях декількох прийомів. Наприклад, розповідь як метод навчання в лекції може бути прийомом активізації уваги учнів.

Засоби навчання - це сукупність предметів, ідей, явищ і способів дій, які забезпечують реалізацію навчально-виховного процесу (різноманітне навчальне обладнання: книги, словники, наочні посібники, письмове приладдя, лабораторне обладнання, технічні засоби навчання та ін.).

Учитель повинен мати розвинуте педагогічне мислення, уміння самостійно оцінити майбутні навчальні ситуації, можливості методів і прийомів, уміння зробити свій обгрунтований вибір методів чи прийомів навчання в конкретних умовах для кожного заняття, оскільки від цього залежить ефективність навчання 
в сучасному закладі загальної середньої освіти.

Класифікують методи навчання 3 урахуванням того, що вони мають вирішувати дидактичне завдання. У класифікації повинна виявлятися внутрішня сутність методу, форма взаємопов’язаної діяльності вчителя та учнів як засіб управління їхньою пізнавальною діяльністю.

При цілісному підході до питання класифікації методів навчання у сучасній педагогіці відзначається розподіл методів навчання на дві групи традиційні та нетрадиційні. Як ознака відмінності традиційних методів навчання використовується ступінь активності здобувачів освіти, характер їхньої пізнавальної діяльності, психологічні й логічні аспекти тощо. Розрізняють класифікації, в основу яких покладено такі ознаки:

- джерела передачі та сприймання навчального матеріалу (С. Петровський, Є. Голант, Д. Лордкіпарідзе, М. Верзілін): словесні (вербальні), наочні та практичні;

- логіка передачі та сприймання навчальної інформації (С. Шаповаленко): індуктивні та дедуктивні;

- ступінь керівництва навчальною роботою (П. Підкасистий, Б. Паламарчук, В. Паламарчук): робота під керівництвом педагога, самостійна робота учнів; - рівень самостійності пізнавальної діяльності (М. Скаткін, І. Лернер): пояснювально-ілюстративні, репродуктивні, методи проблемного викладу знань, частково-пошукові (евристичні), дослідницькі;

- дидактичні цілі, які необхідно вирішувати на конкретному етапі навчання (М. Данилов, Б. Ссипов): методи оволодіння знаннями, формування умінь i навичок, застосування отриманих знань, умінь і навичок;

Ю. Бабанський виокремлює три великі групи методів навчання, в основу яких покладено:

1) організацію та здійснення навчально-пізнавальної діяльності;

2) стимулювання і мотивацію навчально-пізнавальної діяльності;

3) контроль і самоконтроль навчально-пізнавальної діяльності.

На думку М.Фіцули, поширеною $є$ класифікація методів навчання за 
джерелами передавання i характером сприймання інформації. У iï межах виокремлюють словесні, наочні, практичні методи [646, с. 153].

\section{Характеристика окремих методів навчання}

1. Словесні методи. До них належать пояснення, інструктаж, розповідь, бесіда, навчальна дискусія й ін. [там же, с. 153-155].

Пояснення. Це словесне тлумачення понять, явищ, принципів дії приладів, слів, термінів тощо. Використовують переважно під час викладання нового матеріалу, а також у процесі закріплення, особливо тоді, коли учитель відчуває, що учні чогось не зрозуміли. Пояснення часто супроводжується різними засобами унаочнення, спостереженням, дослідами. Успіх пояснення залежить від його доказовості, логічності, чіткості, образності мовлення.

Інструктажс. Як метод навчання він має інформативно-локальний характер, близький до розпорядження алгоритмічного типу. Його застосовують на лабораторних, практичних заняттях, а також під час підготовки до самостійної роботи.

Розповідь. Це монологічна форма викладання. Застосовують іiі за необхідності викласти навчальний матеріал системно, послідовно. Елементами розповіді $є$ точний опис, оповідь, логічне обгрунтування фактів. Розповіді поділяють на художні, науково-популярні, описові. Художня розповідь - це образний переказ фактів, вчинків дійових осіб (наприклад, розповіді про географічні відкриття, створення мистецьких шедеврів тощо). Науковопопулярна розповідь передбачає теоретичний аналіз певних явищ. Описова розповідь є послідовним викладенням ознак, особливостей предметів і явищ навколишньої дійсності.

Бесіда. Це метод навчання, за якого вчитель за допомогою запитань спонукає учнів до відтворення набутих знань, формування самостійних висновків та узагальнень на основі засвоєного матеріалу.

За призначенням у навчальному процесі розрізняють: вступну бесіду (проводиться під час підготовки до заняття, екскурсії, вивчення нового матеріалу); бесіду-повідомлення (грунтується переважно на спостереженнях, організованих учителем на заняттях за допомогою наочних посібників, а також 
на матеріалах текстів літературних творів, документів); бесіду-повторення (використовують для закріплення навчального матеріалу); контрольну бесіду (вдаються до неї при перевірці засвоєних знань).

За характером діяльності учнів виокремлюють: репродуктивну бесіду (спрямована на відтворення засвоєного матеріалу); евристичну, або сократівську (учитель запитаннями спонукає учнів до формулювання нових понять, висновків, правил, використовуючи набуті ними знання, спостереження); катехізисну (спрямована на відтворення тверджень, що потребують дослівного запам’ятовування).

Ефективність будь-якого виду бесіди залежить від вмілого формулювання запитань, а також від якості відповідей (повнота, чіткість, аргументованість).

Навчальна дискусія. Дискусія є публічним обговоренням важливого питання і передбачає обмін думками між учнями або учителем та учнями. Вона розвиває самостійне мислення, вміння обстоювати власні погляди, аналізувати й аргументувати твердження, критично оцінювати чужі і власні судження. Під час навчальної дискусії обговорюють наукові висновки, дані, що потребують підготовки за джерелами, які містять ширшу інформацію, ніж підручник. Дискусія спрямована не лише на засвоєння нових знань, а й на створення емоційно насиченої атмосфери, яка б сприяла глибокому проникненню в істину.

2. Наочні методи навчання. Сутність їх полягає у використанні зображень об’єктів і явищ. До цих методів належать ілюстрування, демонстрування, самостійне спостереження [646, с. 155].

Ілюстрування. Полягає воно в застосуванні посібників, плакатів, географічних та історичних карт, схем, рисунків на дошці, картин, фотографій, моделей тощо. Ілюстрації до навчального матеріалу полегшують його сприймання, сприяють формуванню конкретних уявлень, точних понять.

Демонстрування. Цей метод передбачає показ матеріалів у динаміці (використання приладів, дослідів). Він ефективний, коли всі учні мають змогу сприймати предмет або процес. Учитель зосереджує увагу на основному, допомагає виокремити суттєві аспекти предмета, явища, супроводжуючи показ 
поясненням, розповіддю.

Самостійне спостереження. Це безпосереднє самостійне сприймання явищ дійсності у процесі навчання. Методика організації будь-якого спостереження передбачає кілька його етапів: інструктаж щодо мети, завдань і методики спостереження; фіксація, відбір, аналіз та узагальнення його результатів. Виконану роботу слід обов'язково оцінювати.

3. Практичні методи навчання. Ці методи передбачають різні види діяльності учнів та учителя, а також самостійність здобувачів освіти у навчанні. До них належать вправи, лабораторні і практичні роботи [646, с. 155-156].

Bnрави. За своєю суттю вони є багаторазовим повторенням певних дій або видів діяльності 3 метою їх засвоєння, яке спирається на розуміння $\mathrm{i}$ супроводжується свідомим контролем і корегуванням. У навчальному процесі використовують такі види вправ: niдzотовчі (готують учнів до сприймання нових знань і способів їх застосування на практиці); вступні (сприяють засвоєнню нового матеріалу на основі розрізнення споріднених понять і дій); пробні (перші завдання на застосування щойно засвоєних знань); тренувальні (сприяють формуванню навичок у стандартних умовах: за зразком, інструкцією, завданням); творчі (за змістом і методикою виконання наближаються до реальних життєвих ситуацій); контрольні (переважно навчальні: письмові, графічні, практичні вправи).

Лабораторні роботи. Їх цінність як методу полягає в тому, що вони сприяють зв'язку теорії з практикою, озброюють учнів методами дослідження у природних умовах, формують навички користування приладами, вчать обробляти результати вимірювань і робити правильні наукові висновки.

Практичні роботи. Як метод навчання вони спрямовані на формування вмінь і навичок, необхідних для життя і самоосвіти. Виконання таких робіт допомагає конкретизації знань, розвиває вміння спостерігати і пояснювати сутність явищ.

4. Методи навчання залежно від характеру пізнавальної діяльності учнів.

1. Пояснювальний (інформаційно-репродуктивний).

2. Репродуктивний, заснований на відтворенні знань, повторенні способів діяльності і завдань. 
3. Проблемний виклад.

4. Частково-пошуковий.

5. Дослідницький метод, завдяки якому учені беруть участь у науковому пізнанні.

5. Бінарні методи навчання. Останніми роками набула поширення класифікація, яка відштовхується від суті процесу навчання як двостороннього процесу, - бінарна, в якій виділяються методи навчання і методи учіння (М. Махмутов) (див. табл. 1).

Таблиця 1.

Бінарні методи навчання

\begin{tabular}{|c|c|}
\hline Методи навчання & Методи учіння \\
\hline Інформаційно-повідомлювальний & Виконавський \\
Пояснювальний & Репродуктивний (відтворюючий) \\
Інструктивно-практичний & Продуктивно-практичний \\
Пояснювально-спонукальний & Частково-пошуковий \\
Спонукальний & Пошуковий \\
\hline
\end{tabular}

6. Логічні методи навчання: аналітичний, синтетичний, аналітикосинтетичний, індуктивний, дедуктивний, традуктивний, метод аналогій.

7. Методи стимулювання і мотивації навчання (за Ю. К. Бабанським) [649, c. 202-204].

- Методи емочійного стимулювання $і$ розвитку пізнавального інтересу (створення ситуації успіху (підбір завдань зростаючої складності, диференційована допомога, заохочення в навчанні, використання дидактичних та ділових ігор).

- Методи стимулювання $i$ мотивачиї обов'язку $i$ відповідальності, що передбачають формування розуміння учнями особистої значущості навчання, пред’явлення вимог, оперативний контроль, гуманне покарання.

\section{Активні методи навчання}

Сьогодні для підвищення ефективності процесу навчання у закладах загальної середньої освіти (3ЗСО) дедалі частіше застосовують так звані активні 
методи. Як стверджує В. Ортинський, вони допомагають розкріпачити свідомість, активізувати інтелектуальний i розумовий потенціал особистості, набути необхідних практичних навичок і вмінь.

Активними методами навчання можна назвати ті, що відповідають таким умовам:

- ставлять учнів у становище активних учасників процесу навчання;

- дозволяють значно підвищити ефективність використання навчального часу;

- забезпечують реальний зріст знань, навичок і вмінь;

- формують соціально-ціннісні позиції, необхідні для психологічних якостей, акмеологічних інваріантів і практичного досвіду [647, с. 225226].

Залежно від формування системи знань, умінь і навичок класифікацію активних методів можна представити наступним чином:

- неімітаційні методи (проблемна лекція; лекція удвох; лекція 3 запланованими помилками; лекція-прес-конференція; евристична бесіда; навчальна дискусія; самостійна робота з літературою тощо);

- імітаційні методи (ділова гра; «мозковий штурм»; інсценізації; «круглий стіл» тощо).

А. Смолкін запропонував таку класифікацію методів активного навчання для закладів освіти. Він розрізняє імітаційні методи активного навчання, тобто форми проведення занять, у яких навчально-пізнавальна діяльність побудована на імітації професійної діяльності. Імітаційні методи діляться на ігрові й неігрові. До ігрових відносяться проведення ділових ігор, ігрового проєктування тощо, а до неігрових - аналіз конкретних ситуацій, рішення ситуаційних завдань й інші. Схематично дану класифікацію можна представити в такий спосіб $[650$, с. 86] (див. табл. 2). 
Таблиця 2.

Активні методи навчання

\begin{tabular}{|c|c|c|}
\hline \multirow{2}{*}{ Неімітаційні } & \multicolumn{2}{|c|}{ Імітаційні } \\
\cline { 2 - 3 } & Iгрові & Hеігрові \\
\hline проблемна лекція, лекція вдвох, & ділова гра; & \\
лекція із заздалегідь & педагогічні ситуації; & \\
запланованими помилками, & педагогічні завдання; & колективна \\
лекція прес-конференція; & ситуація & розумова діяльність \\
евристична бесіда; навчальна & інсценування різної & \\
дискусія; самостійна робота 3 & діяльності & \\
літературою; семінари; дискусії & . & \\
\hline
\end{tabular}

Залежно від змісту та організації навчання у педагогічній науці серед інших видів навчання виокремлюється проблемне навчання - така організація процесу навчання, в основі якої лежить створення вчителем проблемних ситуацій, визначення і формулювання проблем, їх розв'язання учнями самостійно або під керівництвом педагога. Так, В. Ортинський зазначає, що проблемний метод передбачає активізацію мислення учнів у процесі читання лекції через постановку проблем, які треба розв'язати. Розв'язуючи їх у взаємодії з учителем, аудиторія формулює теоретичні узагальнення, робить висновки [647, с. 225-226].

Проблема - такий різновид питання, відповідь на яке не міститься в накопичених суб'єктом знаннях і способах діяльності, тому вимагає відповідних практичних і теоретичних дій, відмінних від простого інформаційного пошуку. Проблема повинна містити пізнавальне утруднення, бути пов'язаною з емоціями суб'єкта, передбачити неможливість висувати гіпотези, відбивати специфіку науки, навчальної дисципліни.

Проблемна ситуація - це ситуація, яка виникає внаслідок такої організації взаємодії учнів з об'єктом пізнання, яка допомагає виявити пізнавальне протиріччя. Характеризується інтелектуальним утрудненням і потребою розв'язати його. Суть пізнавального протиріччя міститься в неможливості за допомогою тих знань і способів діяльності, якими володіє суб'єкт, вирішити протиріччя, що виникли. 
Головний метод проблемного навчання - логічно стрункий усний виклад, що точно і глибоко висвітлює основні положення теми. Монологічнопроблемний метод полягає в поданні навчального матеріалу через розв'язання проблемних ситуацій у монолозі вчителя, тобто педагог сам висуває, розкриває і розв'язує проблемні ситуації [647, с. 226].

Навчальна проблема i система супідрядних підпроблем, складених учителем, «вписуються» в логіку викладу. Педагог за допомогою відповідних методичних прийомів (постановка проблемних та інформаційних питань, висування гіпотез, їх підтвердження або спростування, аналіз ситуації та ін.) спонукає здобувачів освіти до спільних роздумів, пошуків невідомого знання. Спілкування діалогічного типу відіграє найважливішу роль у проблемному навчанні, оскільки монолог наближає навчання до інформаційної форми викладу.

Метод діалогічного викладення полягає в тому, як стверджує В. Ортинський, що вчитель, пояснюючи матеріал, залучає учнів до процесу не тільки пошуку розв'язання, а й формування проблем. Це складний метод, але він тісно пов'язаний із розвитком особистості, бо навчає розумових дій, виховує творчість. У результаті критичного осмислення учень вчиться «бачити» проблеми, задавати проблемні запитання, виховувати в собі почуття проблемної ситуації. Цей метод забезпечує найвищий рівень навчання [там же].

До основних методичних інновацій, пов'язаних із використанням активних, або як їх ще називають інтерактивних, методів навчання на основі активізації та інтенсифікації діяльності учнів науковці відносять і кейстехнології (кейс-метод, метод аналізу ситуацій - Case-Study), які посідають значне місце поруч із тренінгами, діловими та рольовими іграми, навчальними груповими дискусіями, мозковим штурмом тощо ([651], [652], [653], [654], [655], [656]). Кейс-метод можна назвати методичним і ментальним переломом в освіті.

Суть його полягає в тому, що учням пропонують осмислити реальну життєву ситуацію, опис якої одночасно відображає не тільки яку-небудь практичну проблему, але й актуалізує визначений комплекс знань, який необхідно засвоїти при розв'язанні даної проблеми. При цьому сама проблема не має однозначних рішень. 
М. Михайліченко та Я. Рудик характеризують кейс-метод як технологію через шість основних ідей.

По-перше, мета навчання відрізняється від класичної схеми - навчити, дати єдино «правильні», раз і назавжди визначені знання, вміння та навички. Навчальний процес орієнтований на усвідомлення не єдиної, а багатьох істин. Учні разом з учителем розв'язують пізнавальну проблему, яка має декілька варіантів вирішення, кожен із яких претендує на істину.

По-друге, кейс-методу властивий демократичний характер процесу одержання знань. Учень є рівноправним із іншими учасниками обговорення проблеми, у тому числі з учителем. Останній є не лектором, «ментором», «істиною в останній інстанції», а організатором, співбесідником. Головним у навчанні $є$ вироблення знань у процесі співтворчості учня й учителя.

По-третє, результатом застосування кейс-методу $є$ не лише знання, а й практичні навички. Здобувачі освіти мають можливість отримати інформацію про сучасні методи, прийоми, технології, а також спробувати їх застосувати, оволодіти навичками роботи за певною технологією.

По-четверте, технологія застосування кейс-методу $є$ досить чіткою i простою. За певними правилами розробляється модель конкретної ситуації, яка має місце в реальному житті, та комплекс знань, практичних навичок, необхідних для іiі вирішення. Ця модель має вигляд тексту обсягом від 10 до 50 сторінок, який і називається «кейсом». Учні попередньо вивчають його, залучаючи й інші джерела інформації. Потім зміст кейсу детально обговорюється на заняттях та диспутах, де вчитель виконує роль диспетчера процесу співтворчості - генерує запитання, фіксує відповіді, підтримує дискусію.

По-n'яте, перевагою кейс-методу є не лише отримання знань і формування практичних навичок, а й розвиток системи цінностей учнів, їхніх життєвих установок і позицій, своєрідного світосприймання.

По-шосте, кейс-метод дає можливість отримати задоволення від пізнання нового, адже долається такий «непоборний» дефект традиційного навчання, як сухий, неемоційний виклад матеріалу [653, с. 459-460]. 
Крім цього, кейс-технологія, як досить ефективна методика навчання, оптимально поєднує теоретичні знання учнів з умінням самостійно орієнтуватися в ситуації. Кейс-метод (метод аналізу ситуацій) на основі використання теоретичних знань дає змогу оволодіти також методологією аналізу ситуації, набути досвіду, чого інші методики не забезпечують із такою ж ефективністю [653, с. 459-460].

Метод ситуаційного навчання, як стверджують О. Сидоренко та В. Чуба, базується на суттєво інших принципах, які дають інше визначення ролей вчителя й учня. Обов’язок педагога - мотивувати зацікавлення учнів у предметі: створити таке середовище у класі, яке заохочує учнів ділитися власними ідеями, знаннями і досвідом і брати участь в аналітичному процесі. Обов’язком учня $є$ привнесення в навчальний процес своєї активної уваги. Учень повинен бути переконаним у тому, що він несе особисту відповідальність за своє навчання: «Вчитель знаходиться поруч, щоб допомогти мені, і я повинен використати цю допомогу, але кінцева відповідальність за це лежить на мені». Мета і вчителя, й учня - створити у класі таке середовище, в якому здобувачі освіти можуть розвинути чи хоча б застосувати ті навички пізнання і поведінки, які будуть їм потрібні для вирішення проблем, що чекатимуть їх у майбутній професійній діяльності. Педагоги заохочують учнів і тим самим стимулюють їхні зусилля взяти відповідальність за своє навчання. Відповідно, здобувачі освіти стимулюють зусилля вчителів щодо розвитку їхніх здібностей [654, с. 37$]$.

В основі цієї методики лежить розгляд, аналіз, пошук рішення у так званій ситуаційній вправі.

Ситуаційна вправа - це комплексний опис реальної ситуації, яка мала місце на практиці. Проблема, що розглядається в ситуаційній вправі, вимагає збирання відповідних даних, встановлення точного діагнозу i/aбо формування прогнозу та вибору «найкращого» рішення з огляду на прийняті критерії оцінки.

Як пише Х. Д. Граг, «ситуаційні вправи - це каталізатори, які прискорюють процес навчання на досвіді» [там же].

До діалогових технологій навчання - системи діяльності педагога й учнів, пов’язаної зі створенням комунікативного середовища, розширенням простору 
співпраці на рівні «учитель - учень», «учень - учень», «учень - автор», «учитель - автор» у ході постановки й вирішення навчально-пізнавальних завдань науковці відносять дискусію, яка є:

- процесом обговорення проблеми, способом її колективного дослідження, протягом якого кожна зі сторін, через аргументацію (відстоювання) або спростування (опонування) думки співрозмовника (опонента), претендує на монопольне встановлення істини;

- методом навчання, що підвищує інтенсивність й ефективність процесу сприйняття за рахунок активного включення учнів у колективний;

- спеціальним лінгводидактичним методом, кінцевою і головною метою застосування якого є комунікативно-стратегічна компетентність учня [657, с. 64];

- пошуком істини шляхом зіставлення різних точок зору [655, с. 175-184], [656, c. 16-18], [658, c. 70-76].

Групова дискусія - це колективне обговорення якої-небудь проблеми, кінцевою метою якого є досягнення певної загальної думки щодо неї. У ході дискусії відбувається колективне зіставлення думок, оцінок, інформації 3 обговорюваної проблеми (див. рис. 1).

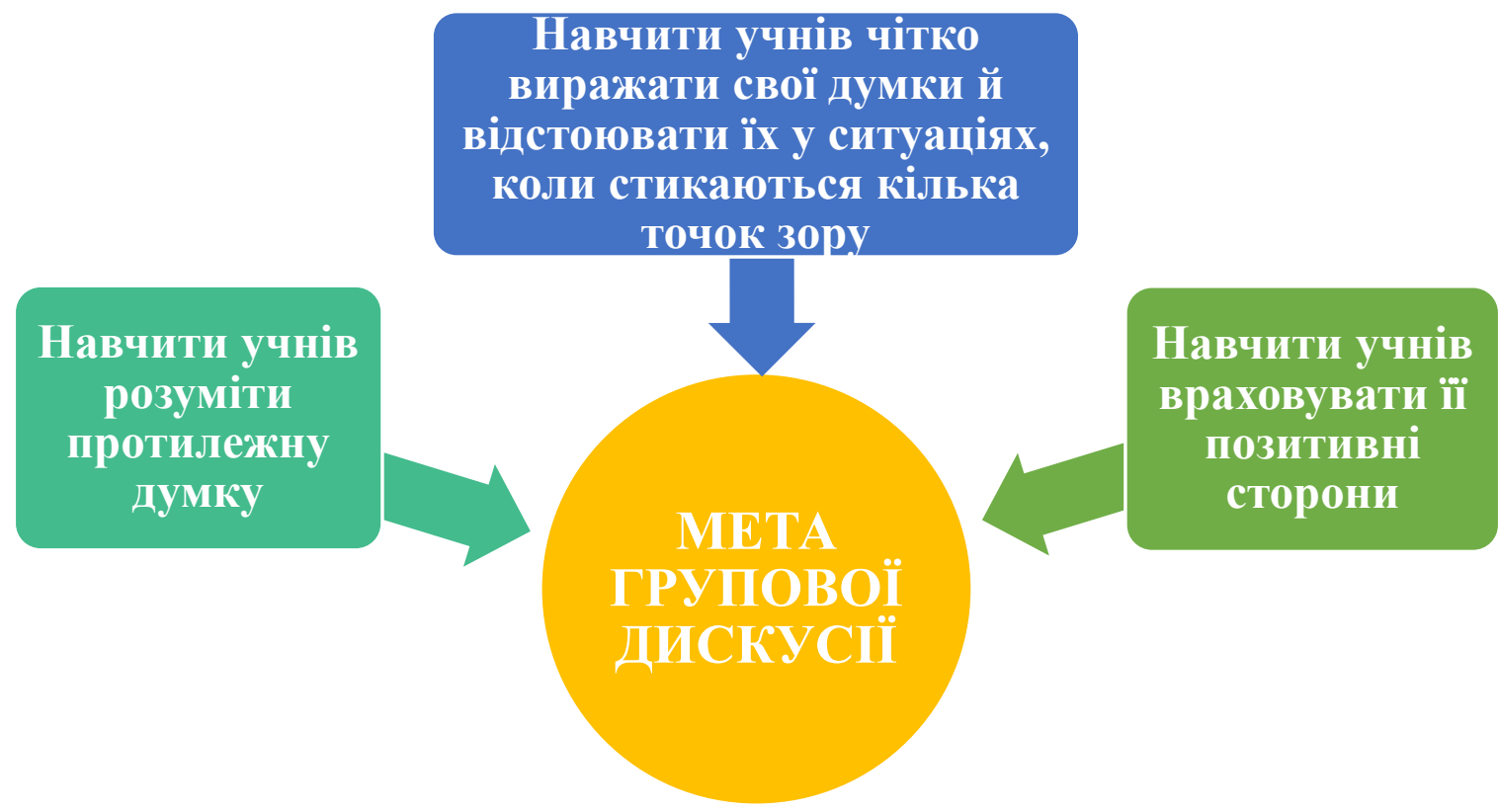

Рисунок 1. Мета групової дискусії 
П. Фенрих, визначаючи конкретну мету дискусії на занятті чи зустрічі, виділяє три важливих види розмови: власне дискусія, дебати та переговори (див. табл. 3) [658, с. 72].

\section{Таблиця 3.}

Види розмов. Використовується тоді, коли метою є спільний пошук істини, найкращого виходу із ситуації, коли потрібно розглянути проблему з багатьох позицій, перш ніж настане час для прийняття рішення, коли важливим є залучення у спільний процес мислення досвіду багатьох учасників. У дискусії необхідно слухати партнера чи вчителя, для того щоб

Дискусія якнайкраще зрозуміти, якнайповніше сприйняти його спосіб мислення та досвід. Намагатися бути найбільш відкритим до всього, що є новим і навіть незвичним. Не відкидати жодного почутого формулювання чи аргументу, поки його ретельно не обмірковано. Охоче погоджуватися на гіпотетичне продовження розмірковувань, $з$ якими можна не погоджуватися, оскільки важливо знати, куди це розмірковування веде...

Є чудовими, коли йдеться про гостре одночасне бачення проблеми, коли погляди розділені поміж учасниками групи, яка повинна здійснити вибір, а не узгодити позиції. Дебати - це форсування власної позиції, «війна словами», прагнення виграти, показати себе кращим перед третіми особами. У

Дебати дебатах треба слухати партнера (в певному сенсі суперника) 3 тим, щоб знайти найкращий аргумент проти його тези, уточнювати та відточувати власну позицію, намагатися показати абсурдність висловлювань іншої сторони, вказувати на всі слабкі сторони iї аргументації. У дебатах найчастіше не йдеться про переконання противника - ставкою є мислення та вибір, 
зроблений слухачами. Бувають провокаційні дебати, в яких противник намагається найгостріше висловитися проти тези лише для того, щоб захист, прихильники тези, могли їх відкинути і тим самим ще міцніше підтримати тезу. Добрим прикладом дебатів є оксфордські дебати.

Використовуються тоді, коли метою є узгодження спільної дії, коли необхідні знання вже зрештою має кожен з учасників групи, натомість потрібно почати спільну дію. У переговорах Переговори треба слухати партнера, щоб виловити всі спільні елементи, які вселяють надію на гармонію, співпрацю або хоча б можливий компроміс. Якщо в дебатах спеціально загострюється суперництво, то в переговорах іде пошук таких розв'язків, які створять можливості для співпраці, незважаючи на відмінності.

«Mозковий штурм» - переклад назви brainstorming, котру започаткував як метод активного пізнання дійсності американський психолог Алекс Осборн [659, c. 110]. Найпоширенішими перекладами назви, є такі: «мозкова атака», «атака мізків», «конференція ідей». Основна концепція мозкового штурму як методу навчання грунтується на теорії 3. Фройда, яка в той час була поширена в США.

Дискусія «мозковий шттрм» (метод аглютинації), як стверджують науковці - це форма дискусії, за допомогою якої колективно (у складі групи чи експертів) обговорюється наукова чи практична проблема/навчальне питання, здійснюється пошук шляхів щодо розв'язку через вільне висловлювання думок, ідей та пропозицій усіх учасників, використання великої кількості взаємних асоціацій між ними [655, с. 190], [656, с. 12], [658, с. 77], [659, с. 46]. Мета цієї технології - звільнити учнів від інерції та стереотипів мислення, забезпечити процес генерування ідей, без їх аналізу та обговорення, завдяки виникненню асоціацій в учасників, організувати колективну розумову діяльність із пошуку нетрадиційних шляхів щодо вирішення запропонованої проблеми. В освітньому процесі використання цього методу дозволяє вирішити наступні завдання: 
- активізувати навчально-пізнавальну діяльності учнів;

- сформувати здатність фокусування уваги i розумових зусиль на вирішенні актуального завдання;

- творче засвоїти навчальний матеріал;

- поєднати теоретичні знання із практикою;

- сформувати досвід колективної розумової діяльності. Проблема, що формулюється на занятті, за методикою мозкового штурму, повинна мати теоретичну або практичну актуальність і викликати активний інтерес учнів. Загальна вимога, яку необхідно враховувати при виборі проблеми для мозкового штурму, - можливість використання багатьох неоднозначних варіантів вирішення проблеми, яка висувається перед учнями як навчальне завдання.

Ще одним інтерактивним методом за участю виключно учнів $є$ «круглі столи» - один із активних методів проведення навчальних занять, який має на меті розвиток і вдосконалення самостійності учнів, їхнього логічного мислення, соціальної та моральної зрілості, формування поглядів і переконань, оволодіння методами аналізу та синтезу, уміннями робити висновки й вносити пропозиції, розв'язувати суперечки в процесі дискусії щодо попередньо визначених тем. Це форма публічного обговорення або висвітлення будь-яких питань, коли учасники висловлюються у визначеному порядку (спершу - сидячи за столом, який має круглу форму); нарада або обговорення певних питань, де присутнім надають рівні права стосовно один одного. Круглий стіл - це обмін думками з якогонебудь питання, проблеми, що цікавить учасників спілкування [656, с. 21-22].

Характерною рисою «круглого столу» є поєднання тематичної дискусії 3 груповою консультацією: поряд 3 активним обміном знаннями, в учнів виробляються вміння викладати думки, аргументувати свої міркування, обгрунтовувати запропоновані рішення і відстоювати свої переконання. При цьому відбувається закріплення інформації та самостійної роботи з додатковим матеріалом, а також виявлення проблем і питань для обговорення. Беручи участь у круглому столі, учень висловлюється від своєї особи. Проблеми, які 
обговорюються за «круглим столом», можуть бути різноманітними. Участь у круглому столі дозволяє закріпити отримані раніше знання, заповнити відсутню інформацію, сформувати вміння вирішувати проблеми, зміцнити позиції, навчити культурі ведення дискусії [660, с. 49].

У психолого-педагогічній науці немає чіткої визначеності щодо трактування сутності гри, яка використовується у навчальному процесі. Для позначення цього виду навчальної діяльності учнів учені використовують низку понять («ділова гра», «навчальна ділова гра», «навчальна гра», «рольова гра», «навчальна рольова гра», «дидактична гра» тощо).

Як стверджує С. Сисоєва, рольова гра є спрощеною модифікацією ділової гри, що моделює менш складну проблему професійної / навчальної діяльності. У процесі рольової гри відбувається знайомство з новими для учасників ролями (наприклад, керівника групи); потім опановуються нові форми спілкування i засоби прийняття рішень. «Гравці», спілкуючись один з одним, емоційно реагують, проявляють пізнавальний інтерес до проблеми і до самих себе. Рольова гра починається 3 аналізу конфліктної ситуації. Учитель ставить перед учасниками задачу щодо прийняття рішення в загальних рисах. Потім між учасниками розподіляються ролі, й після невеличкої підготовки проводиться ігровий етап і післярольовий аналіз [655, с. 188].

Групі експертів учитель доручає фіксувати роботу кожного учасника, його поведінку, креативність, адекватність засобів спілкування тощо. Готуючи і проводячи гру, педагог повинен бути готовий у будь-який момент включитись до неї і на якийсь проміжок часу замінити персонажа.

Учитель має можливість оцінити як індивідуальну діяльність кожного 3 учасників гри, так і групову взаємодію. У рольовій грі відпрацьовуються як горизонтальні соціальні зв'язки (однокласники, які займають однакові позиції) так і вертикальні (учитель - учень). Учні вчаться діловому спілкуванню, спільній діяльності, командному (якщо це передбачено сценарієм) прийняттю рішення, відповідальності за прийняте рішення, за точність його виконання незалежно від того, погоджується людина з ним чи ні (адже в неї роль підлеглого). Крім того, 
учасники гри повинні вчитися стримувати емоції, амбіції, будувати власну i спільну діяльність, орієнтуючись на кінцеву мету.

О. Дацків вважає драматизацію ефективним засобом формування комунікативних навичок і вмінь та визначає iї як сукупність прийомів взаємодії учителя та учнів у драматичних і рольових іграх, імпровізаціях, симуляціях та театральних проєктах, спрямованих на формування комунікативної компетентності. Науковиця виокремлює п’ять найпоширеніших прийомів драматизації: драматичні ігри, рольові ігри, імпровізащії, симуляияї, театральні проєкти [661, с. 54-57].

Драматична гра базується на дії, розвиває уяву, сприяє засвоєнню нових мовних структур і дозволяє виявляти емоції лінгвістичними та паралінгвістичними засобами. Драматичні ігри, як правило, є короткими, можуть проводитися на будьякому етапі заняття, хоча найчастіше застосовуються учителями як розминка на початку. Такі ігри є важливим засобом організації групової роботи. Вони можуть i повинні застосовуватися для підготовки учнів до участі у більш складних прийомах драматизації, таких як: рольова гра, імпровізація, симуляція та театральний проєкт.

Рольова гра-драматизація допомагає учням-учасникам уявити себе і діяти у нових обставинах, а також відчути і зрозуміти поведінку, думки й емоції іншої людини, роль якої вони гратимуть. Рольові ігри-драматизації мають важливу особливість: на відміну від рольових ігор, учасники яких виконують узагальнені, стандартизовані соціальні ролі (пасажир, поліцейський, пілот і т. д.), які не мають особистісних характеристик i відтворюють стандартні ситуації повсякденного життя, рольові ігри-драматизації передбачають наявність персонажів, наділених усіма особистісними характеристиками (стать, вік, соціальний і сімейний статус), певної їх кількості і проблемної / конфліктної ситуації, у якій діють учасники гри.

Iмпровізація - гра без планування чи підготовки. Метою імпровізації є повна спонтанність. У здобувачів освіти немає часу на підготовку, вони знайомляться зі своїми ролями та ситуаціями безпосередньо перед початком роботи. Вчителю потрібно підготувати лише список ситуацій для імпровізації. У методичній літературі зустрічається також термін «керована (guided) імпровізація». Цьому виду імпровізації передує підготовча робота, яку 
проводить учитель. Імпровізація $є$ необхідною, тому що у реальному спілкуванні iï учасники повинні вміти імпровізувати і бути готовими до цього в будь-який момент. В умовах навчання учень має бути повністю залучений у те, що відбувається на занятті, уявляти, що він має повідомити у навчальній ситуації і як відреагувати на повідомлення інших. Реальність навчальної комунікативної ситуації для імпровізації стимулює іiі учасників до використання уяви й активної участі у спілкуванні. Застосування цієї форми драматизації дозволяє здобувачам освіти формувати впевненість у собі, долати комунікативний бар'єр у спілкуванні з носіями мови.

Симуляція - драматизація, в основі якої лежить подія, учасники якої мають функціональні ролі, обов'язки та достатньо обізнані з проблемою, щоб виконувати ці обов'язки. Втілення повномасштабної симуляції у навчальний процес потребує цілого циклу занять. Кінцевою метою може бути відтворення, скажімо, світу компанії, телевізійної студії, редакції газети чи урядової структури. Зазвичай, учителі відмовляються від застосування цього прийому драматизації на заняттях через брак часу, але погоджуються з тим, що симуляції $\epsilon$ ефективними передусім у розвитку вмінь говоріння.

Tеатральний проєкт охоплює процес підготовки до постановки та відтворення на сцені для глядачів літературної або створеної самими учнями вистави. Метою такого проєкту є і процес підготовки, і результат - сама вистава. Цю форму драматизації дослідники визначають також як театралізацію. Однак, на думку О. Дацків, термін «театральний проєкт» більш вдалий, бо він включає у себе обидва компоненти, визначені вище - підготовку до вистави і їі сценічне втілення [661, с. 55]. 


\section{Характеристика основних елементів вивчення іноземної мови}

та особливості їх взаємодії

\section{Елементи для успішного вивчення іноземної мови.}

Більшість сучасних методів навчання мови намагаються запропонувати розумне поєднання багатьох ідей та елементів (методів і прийомів), розглянутих вище, як можна використовувати надзвичайно корисно.

Сучасна практика навчання мови загалом дає учням можливість подумати про те, як працює частина граматики, i водночас надає можливості для використання мови в комунікативних заходах та процедурах, заснованих на завданнях. Вона пропонує здобувачам освіти безпеку відповідної контрольованої практики (залежно від таких змінних, як вік учнів, особистий стиль навчання та мовлення, про яке йдеться), а також дає їм можливість використовувати будь-яку мову, яку вони знають.

Як стверджує відомий англійський науковець i тренер-викладач Дж. Хармер (J. Harmer) у своїй книзі «How to Teach English» (Як навчати англійської), така еклектика - вибір між найкращими елементами низки різних ідей і методів - є належною відповіддю на конкуруючі вимоги різних тенденцій. Однак небезпека еклектики полягає в тому, що, оскільки вчителі можуть використовувати фрагменти різних теорій і методів, уроки можуть стати неорганізованою формою різних видів діяльності без очевидної узгодженості чи філософії, що їх підкріплюють. Це може бути настільки ж шкідливим, як i методологічна жорсткість, яку прагне замінити еклектика [662, с. 51].

Однак еклектика, яка використовує основну філософію та структуру, тобто принципова еклектика, уникає цих ризиків. Вважаючи, що учні потребують експозиції, мотивації та можливостей для використання мови, і визнаючи, що різні учні можуть більш-менш добре реагувати на різні стимули, це говорить про те, що більшість навчальних послідовностей повинні мати певні характеристики або елементи, незалежно від того, чи відбуваються вони протягом кількох 
хвилин, півгодини, урок або цикл уроків. Такими елементами Дж. Хармер визначає залучення, навчання та активізацію (Engage, Study, Activate) [там же].

Проаналізуємо й охарактеризуємо ці поняття з точки зору Дж. Хармера, а також розглянемо, як вони можуть відбуватися і взаємодіяти в трьох типових послідовностях.

Залучення (Engage). Як вважає англійський науковець, залучення, яке емоційно захоплює учнів на уроці і робить їх пристрасними і допитливими, $\epsilon$ однією із життєво важливих складових успішного навчання. Діяльність і матеріали, які часто залучають учнів, включають: ігри (залежно від віку учнів та типу гри), музику, дискусії, стимулюючі картинки, драматичні історії, забавні анекдоти тощо. Навіть якщо такі дії та матеріали не використовуються, вчителі можуть зробити все можливе, щоб їхні учні залучалися до теми, вправи чи мови, 3 якою вони будуть мати справу, попрохати їх спрогнозувати або пов'язати матеріали уроку зі своїм життям. Багато що залежатиме від того, якими є окремі здобувачі освіти, і наскільки добре вчитель провокує та заохочує їх до участі. Тому причина, чому цей елемент настільки важливий у навчанні послідовностей, полягає в тому, що, коли учні правильно задіяні, їхня участь у етапах навчання та активізації, ймовірно, буде набагато більш вираженою, i, як наслідок, користь, яку вони отримають від цього буде значно більшою [662, с. 52].

Навчання (Study). Навчальна діяльність - це ті заняття, де учнів просять зосередитися на побудові чогось, чи то сама мова, способи іії використання чи те, як вона звучить і виглядає. Навчальна діяльність може варіюватися від зосередження на одному звуці та відпрацювання його до дослідження того, як письменник досягає певного ефекту в довгому тексті; від перевірки й відпрацювання часу дієслова до вивчення особливостей неформального мовлення з метою обговорення розмовного стилю. У процедурі PPP (Presentation, Practice and Production) (презентація, практика та продукування) і презентація, і практика (перші два етапи) зосереджені на побудові елемента граматики або лексики; контрольована практика (де учні повторюють багато фраз, використовуючи мову, на якій вони зосереджуються) покликана змусити учнів замислитися над 
побудовою мови. Коли вчитель змушує учнів повторювати слова із правильною вимовою (або вимовляти слова, які він хоче, щоб вони сказали на основі поданих ним сигналів), це відбувається задля того, щоб учні думали про найкращий спосіб сказати слова. Педагог ставить завдання, щоб здобувачі подумали про побудову вимови слів [там же].

Але навчання, як вважає Дж. Хармер, означає більше, ніж процедура $\boldsymbol{P P P}$ хоча вона $є$ одним із видів навчання. Учні можуть навчатися різними способами. Іноді на уроці вчитель може показати їм новий граматичний шаблон, повторюючи кожен елемент окремо або розміщуючи схему на дошці, перш ніж просити їх повторити речення, і це дуже нагадує процедуру РРР. Але на іншому занятті він може показати учням приклади мови і попросити їх спробувати відпрацювати правила. Такі пошукові заходи спрямовують школярів виконувати всю інтелектуальну роботу, а не залишати тї вчителеві. Іноді здобувачі освіти можуть разом прочитати текст і знайти слова та фрази, на яких вони хочуть зосередитися для подальшого вивчення. На іншому уроці вони можуть проводити час 3 учителем, слухаючи або дивлячись на мову, яку вони використовували, щоб побачити, наскільки вона була більш-менш успішною. Все це (і багато інших можливостей) є прикладами вивчення мовної конструкції [там же, с. 53].

Деякими типовими мовними аспектами для вивчення можуть бути вивчення та відпрацювання голосного звуку (наприклад, 'ship' - 'sheep' 'chip' - 'cheap', 'dip' - 'deep', 'bit' - 'beat', тощо), вивчення та відпрацювання граматичної конструкції (наприклад, the third person singular of the present simple - 'He sleeps', 'she laughs', 'it works' тощо), вивчення та відпрацювання лексичних фраз для запрошення ( 'Would you like to come to the cinema/to a concert?' тощо), вивчення та відпрацювання того, як ми використовуємо займенники в писемному дискурсі

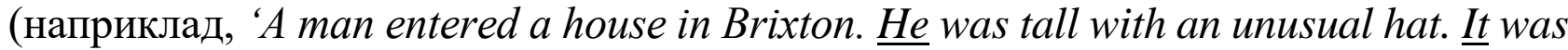
multicoloured ...' тощо), вивчення та практика організації абзацу (topic sentence, development, conclusion) або правил використання 'make’ i ‘do’ [там же].

Активізація (Activate). Цей елемент, як зазначає Дж. Хармер, описує вправи та види діяльності, спрямовані на те, щоб спонукати учнів 
використовувати мову якомога вільніше та більш комунікабельно. Мета активної діяльності полягає в тому, щоб здобувачі освіти використовували будь-яку мову, яка може бути доречною для певної ситуації або теми. Таким чином, школярі отримують можливість використовувати реальну мову з малими обмеженнями або без них - свого роду репетиція для реального світу.

Персоналізація (де учні використовують мову, яку вони вивчали, щоб розповісти про себе або створити власні оригінальні діалоги, часто як третій або продуктивний етап РРP) забезпечує зв’язок між етапами вивчення та активізації. Але вправи для більш справжньої активізації включають рольові ігри (учні розігрують, наприклад, якомога реалістичніше, діалог між туристичним агентом $\mathrm{i}$ клієнтом), створення реклами (наприклад, школярі пишуть, а потім записують радіо-/ відеорекламу), дебати й обговорення, опис і малюнок (Describe and draw) (учень описує оригінал картини/фотографії та пояснює товаришу, що тому потрібно намалювати), написання оповідань і віршів, обмін електронною поштою, групове виконання письмових завдань тощо [662, с. 53].

Однак, як зауважує Дж. Хармер, активізація полягає не тільки в створенні мови в мовленні та письмі. Коли учні читають / слухають на дозвіллі (або коли слухають / читають, щоб зрозуміти повідомлення, а не задумуються про форму мови, яку сприймають), вони залучаються до мовної активізації. Здобувачі освіти використовують будь-яку мову, яка є в їхньому розпорядженні, щоб зрозуміти прочитаний або прослуханий текст.

Школярі можуть, пройшовши етап активізації, повернутися до того, що вони сказали або до прочитаного тексту, і зосередитися на його побудові.

Активізація може бути прелюдією до навчання, а не обов’язково навпаки.

Усі три елементи $\boldsymbol{E S A}$ (Engage, Study and Activate) мають бути у структурі білышості уроків або навчальних послідовностей. Незалежно від основного фокусу уроку (наприклад, граматичної теми чи вправи на навички читання), учні завжди повинні бути залучені, якщо це можливо, щоб вони могли отримати максимальну користь від навчального досвіду. Більшість школярів із готовністю оцінять можливості активізувати свої мовні знання, але для багатьох із них включення навчальних елементів, навіть малих або нетривалих, переконає їх у корисності уроку [там же]. 
Дж. Хармер підкреслює, що деякі активні методи (дебати або рольова гра, тривала пошукова робота в Інтернеті або розширена письмова робота) займають багато часу, і тому за один урок вчителі можуть не захотіти переривати процес активізації певним методом навчання. Але вони можуть захотіти використати цю вправу як основу для вивчення, можливо, на іншому уроці. Те ж саме науковець зауважує і про тривалий період навчання, коли шанси на активізацію невеликі. Але в обох цих випадках єдиним обмеженням $€$ час. Відсутні елементи з'являться в інший час.

Однак навчання й учіння на нижчих рівнях не складається з такої тривалої діяльності. Натомість набагато ймовірніше, що в певній послідовності уроку або періоді буде більше однієї ЕSA послідовності.

\section{Послідовності ESA (залучення, навчання, активізація) уроків}

Як зазначає Дж. Хармер, використання трьох елементів ESA в послідовностях уроків, може відбуватися в різному порядку. По-перше, порядок неодмінно змінюється залежно від того, чого вчитель хоче досягти. Якщо урок проводиться на основі завдань (task-based lesson), то навчальна дія цілком може відбутися після активізації. 3 іншого боку, якщо вводиться частина граматики, то спочатку можна вивчити мову, перш ніж учням давати завдання на іiі використання. По-друге, існує небезпека: якщо вчитель завжди проводить урок в одному порядку, то учням стане нудно; передбачуваність може зменшити ентузіазм і мотивацію учнів - і вчителя також [662, с. 54].

Дж. Хармер пропонує різні послідовності навчання (використання елементів ESA різними способами), у нашій роботі розглянемо три можливості, щоб продемонструвати різноманітність їх застосування на уроках іноземної мови.

Перший тип послідовності навчання веде учнів по прямій i, як наслідок, називається прямими стрілками (straight arrows): спочатку вчитель зацікавлює клас і залучає його до навчання; потім учні вивчають щось; далі вони намагаються активізувати вивчене, запустивши у продукування. Дж. Хармер подає, як приклад, таку послідовність, розроблену для учнів початкових класів, щоб навчати 'can' i 'can't':

1. Залучення: учні та вчитель переглядають зображення, веб-сайт чи DVD iз роботами нового покоління. Можливо, вони зможуть переглянути короткий 
ролик із фільму «I, Robot» або якийсь інший сучасний фільм на подібну тематику. Діти говорять, подобається їм ідея про роботів чи ні.

2. Навчання: вчитель показує учням (малюнок) конкретного робота. Вони знайомляться 3 поняттями 'can' і 'can't' (як вони вимовляються та 3 чого складаються) і говорять такі речення, як 'It can use a cash machine' i 'It can't play the piano'. Вчитель повинен переконатися, що речення вимовляються правильно, а учні правильно користуються граматикою.

3. Активізація: учні працюють у групах, щоб створити та описати роботу своєї мрії. Вони роблять презентацію перед класом, розповідаючи, що їхній робот може, а що ні.

Цей урок можна представити так (див. рис. 2):

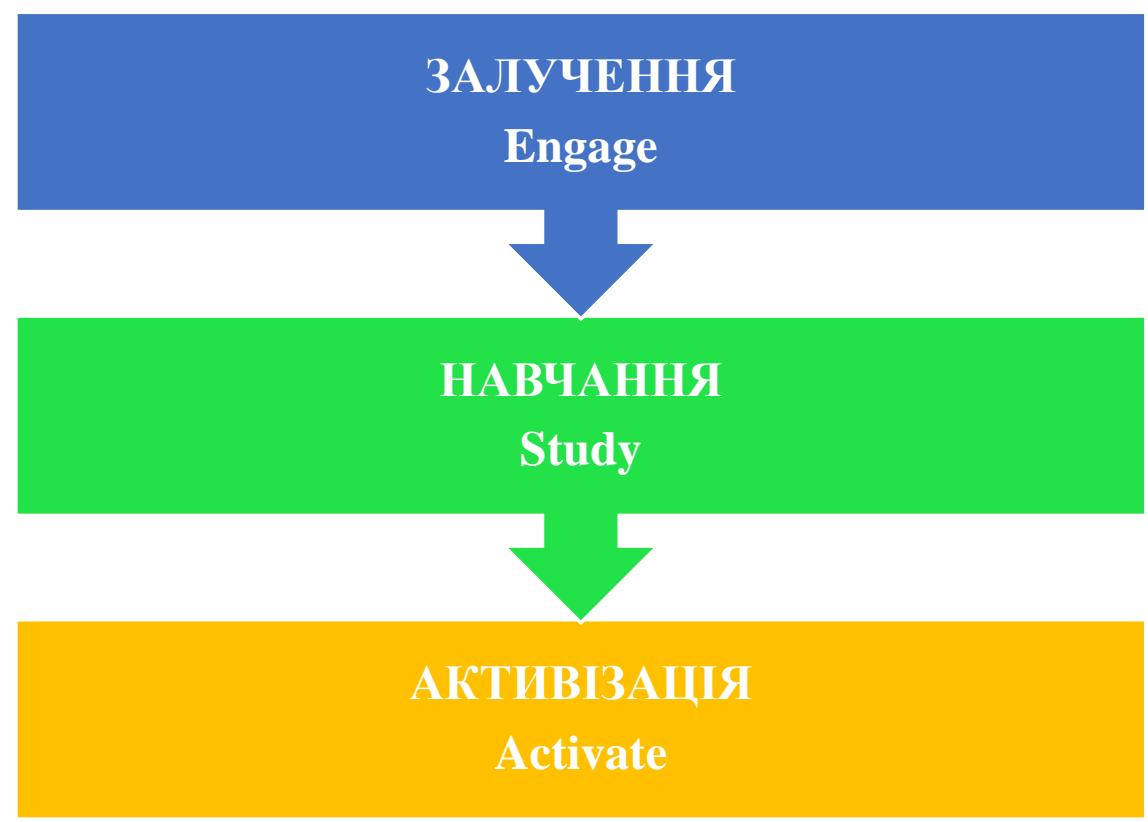

Рисунок 2. ESA straight arrows послідовність

Уроки прямих стрілок (straight arrows), як і процедури РPР (презентація, практика та продукування), дуже добре працюють для певних структур. Вище наведений приклад робота чітко показує, як створюються 'can' i 'can 't' і як вони використовуються. Це дає учням можливість контрольовано практикувати мову (під час фази вивчення), а потім діти можуть активізувати «нову» мову у приємний для них спосіб і ситуаціях. 
Однак, як стверджує Дж. Хармер, ТАКА процедура може працювати на нижчих рівнях для простої мови, але вона може бути не такою підходящою для більш «просунутих» учнів із більш складною мовою. Це не принесе великої користі, якщо вчитель хоче, щоб учні залучилися до читання чи щось обговорювали. Це також не буде дуже корисним, якщо більшість учнів уже вміють використовувати 'can' i 'can't'. Хоча, як зазначає науковець, немає нічого поганого у використанні послідовності прямих стрілок - для правильних учнів на правильному рівні, вивчення правильної мови - це не завжди доречно [662, с. 55].

Натомість, існують інші можливості для послідовності елементів ESA. Ось, наприклад, процедура бумеранга (boomerang procedure):

1. Залучення: учні та вчитель обговорюють проблеми, пов’язані зі співбесідами при прийомі на роботу. Що потрібно пошукачу роботи для хорошої співбесіди? Що хоче дізнатися інтерв’юер? Учням буде цікава ця тема.

2. Активізація: педагог описує ситуацію інтерв’ю, яку учні збираються розіграти в рольовій грі. Школярі готують типи питань, які вони збиратимуться поставити, і типи відповідей, які можуть дати (не зосереджуючи увагу конкретно на побудові мови, а розглядають це як завдання з реального життя). Потім учні розігрують інтерв’ю за ролями. Поки вони це роблять, учитель відзначає мовні труднощі, з якими вони стикаються й окремі помилки, над якими можна буде працювати пізніше.

3. Навчання: коли рольові ігри закінчуються, вчитель працює з учнями над граматикою та лексикою, які викликали у них проблеми. Наприклад, діти можуть порівнювати свою мову з більш правильним використанням і спробувати самостійно розібратися (відкрити), чому допустилися помилки. Учитель може пояснити, які були недоліки, або направити учнів до підручників із граматики тощо. Вони можуть виконувати певну контрольовану практику мови.

4. Активізація: через деякий час учні розігрують за ролями іншу співбесіду, засвоївши свої мовні помилки, яких допустилися минулого разу.

Процедуру бумеранга для такого типу уроків можна представити таким чином (див. рис. 3). У цій послідовності вчитель відповідає на потреби учнів. Їх 
не навчають мові до тих пір, поки вони не продемонструють (на фазі активізації), що їм це потрібно. Як підкреслює Дж. Хармер, це набагато краще, тому що зв'язок між тим, що учні мають вивчити, і тим, чого їх навчають, є більш прозорим. Це також може бути більш доречним для школярів середнього та просунутого рівнів, оскільки вони вже мають достатньо мовних знань, які їм уже доступні для використання на етапі активізації [там же, с. 56].

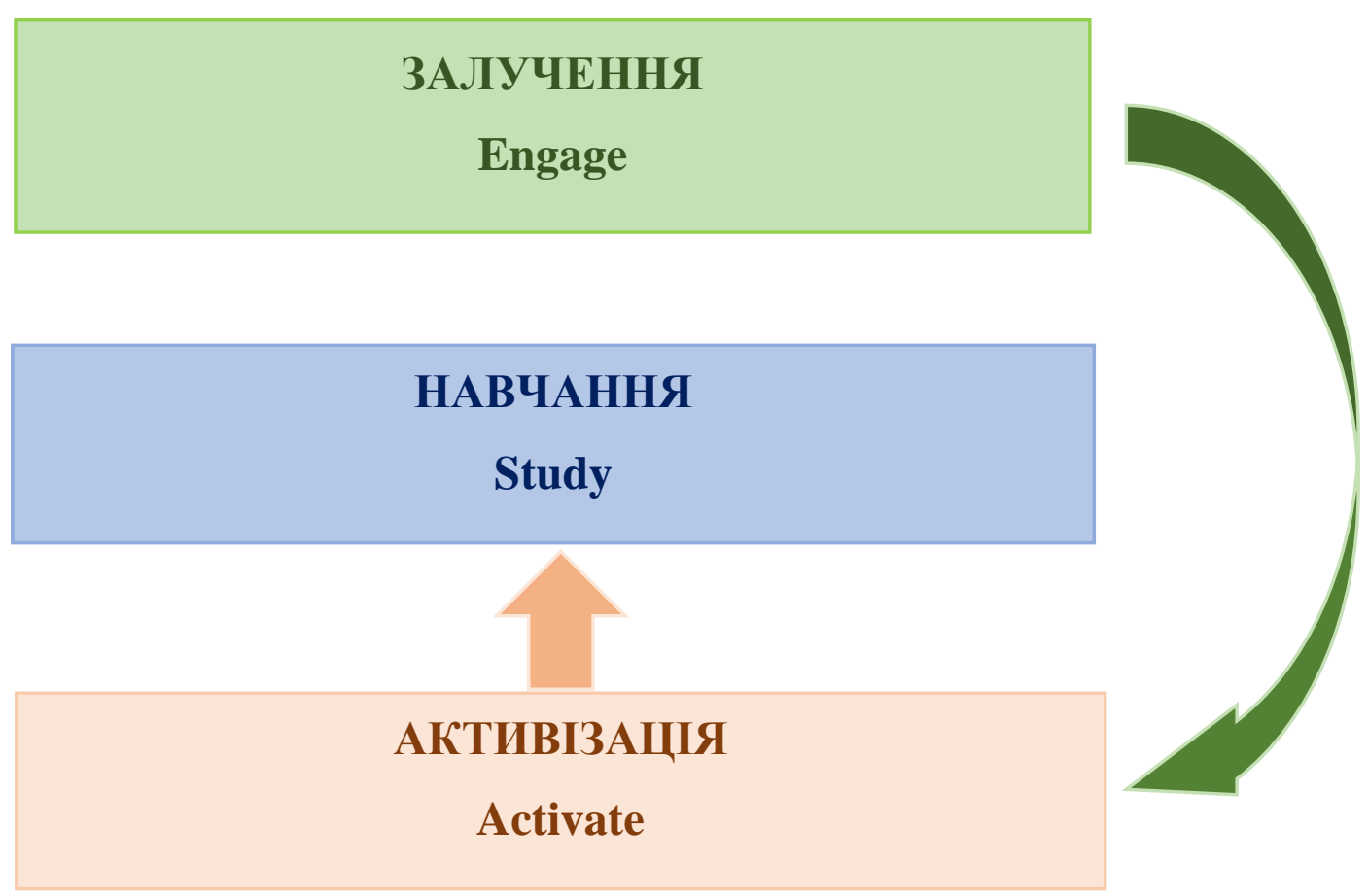

Рисунок 3. EAS(A) boomerang послідовність

Послідовності бумеранга більше схожі на процедури $T B L$ (урок на основі завдань); спочатку завдання, а не конкретна мова. Але потім бумеранг повертається (якщо він знадобиться вчителю), щоб нагадати вивчити частину мови, використану, більш-менш успішно, у завданні. Більш специфічний тип послідовності бумеранга іноді називають тестування-навчання-тестування (test-teach-test), де учнів спочатку просять використати мову на етапі активізації, а потім навчають, як справлятися із ситуаціями, у яких вони допустилися помилки, перш ніж знову спробувати частину тестування.

Однак, більшість уроків, зауважує Дж. Хармер, являють собою суміш процедур і міні-процедур, різноманітних коротких епізодів, що утворюють одне ціле. Ось приклад такого роду уроку-печворку (patchwork lesson): 
1. Залучення $\longrightarrow$ Активізація: учні дивляться на фотографію, на якій зображені відпочиваючі на пляжі, і реагують на неї, коментуючи людей i діяльність, у якій вони беруть участь. Або, діти розглядають принесені свої фотографії сімейних свят тощо. Потім вони розігрують діалог між лікарем і пацієнтом - жертвою сонячних опіків після проведеного дня на пляжі.

2. Активізація: учні проглядають текст, в якому описуються різні люди (3 різними типами шкіри) та вплив сонця на їх шкіру. Далі діти говорять, як вони ставляться до впливу сонця.

3. Навчання: вчитель опрацьовує з учнями лексику (наприклад, 'pale', 'fair-skinned', 'freckles', 'tan'), переконавшись, що вони розуміють значення та природу дефісу деяких із них, а також діти вміють вимовляти їх правильно у відповідних контекстах.

4. Активізація: учні описують свій досвід обгоряння на сонці або людей, яких вони знають, відповідно до прочитаного тексту.

5. Навчання: вчитель зосереджує увагу дітей на використаній у тексті конструкції підрядного речення (наприклад, 'I'm the type of person who always burns' i 'I'm the type of person who burns easily'). Використання такого підрядного речення ('who' clause) обговорюється, й учні практикують використання цієї конструкції (наприклад, 'They're the kind of people who enjoy movies' тощо).

6. Залучення: вчитель обговорює з учнями рекламу: Для чого вона? Якими різними способами реклама намагається досягти свого ефекту? Яку найефективнішу рекламу можуть придумати учні? Вчитель, наприклад, може відтворити якусь радіорекламу або продемонструвати якусь вражаючу візуальну рекламу на проєкторі.

7. Активізація: учні пишуть радіорекламу про сонцезахисний крем. Учитель дозволяє дітям зробити аудіозапис їхніх реклам, використовуючи звукові ефекти та музику.

Послідовність уроку-печворку представлена на Рис. 4). Такі уроки, як наголошує Дж. Хармер, дуже поширені, особливо на середньому та просунутому рівнях. Вони не тільки відображають те, як відбувається процес учіння - досить 
хаотично, не завжди по прямій, - але також забезпечують баланс між навчанням та активізацією, а також мовою та темою [там же, с. 57].

Залучення, навчання та активізація (Engage, Study and Activate) - це основні будівельні блоки для успішного навчання й учіння мови. Використовуючи їх у різних послідовностях, вчителі іноземних мов будуть робити все можливе, щоб сприяти успіху своїх учнів, оскільки різні теорії та процедури щодо вивчення мови, навколо яких сьогодні багато дискусій, відображаються в таких послідовностях, як прямі стрілки, бумеранг та уроки-печворки.

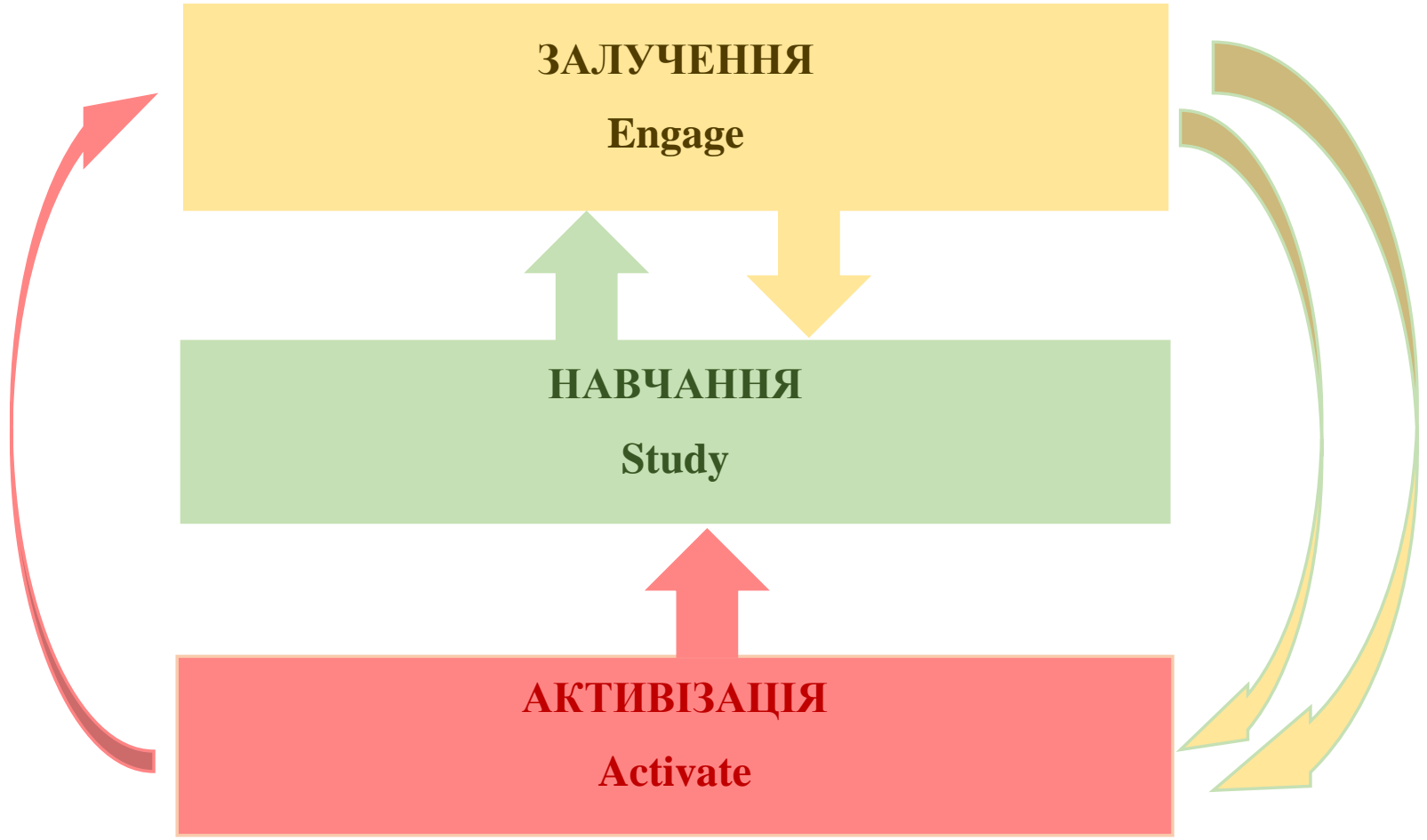

Рисунок 4. EAASASEA patchwork послідовність

\section{ESA та планування}

Плануючи свої уроки, вчителі повинні вирішити, яких очікуваних результатів їхні учні досягнуть до кінця уроку / тижня / місяця. Тоді вони повинні спланувати заняття так, щоб задіяні ними форми, методи та елементи навчання допомогли реалізувати поставлену мету. У цьому контексті, як зазначає Дж. Хармер, балансування трьох елементів ESA:

- нагадуватиме вчителю про необхідність залучення учнів до діяльності;

- спонукатиме забезпечити наявність навчальних заходів, закладених у план; 
- гарантуватиме, що майже на всіх уроках учні матимуть можливість використовувати мову, яку вони вивчають або вивчили. Коли діти намагаються використати мову (взаємодія 3 текстами, спілкування 3 іншими людьми, самостійне продукування мови), то у них задіюються такі ментальні процеси, які роблять їхнє навчання та засвоєння доцільними.

Багато вчителів планують уроки за підручником, який вони обрали для своїх класів. Але навіть якщо уроки базуються на матеріалі підручника, важливо маніпулювати запропонованими у книжці завданнями / активностями так, щоб три елементи (залучення, вивчення й активізація) були наявними у відповідній послідовності.

Отже, можемо зробити наступні висновки:

1. Прийоми і методи активізації пізнавальної діяльності різноманітні. Всіх їх об’єднує одне - вони передбачають поступовий і планомірний розвиток мислення учнів та одночасне формування у них мотивів навчання. Всі прийоми активізації пізнавальної діяльності містять питання, завдання або інше наочне завдання, яке стимулює розумову діяльність всього класу і кожної дитини окремо. Методи активізації пізнавальної діяльності здобувачів освіти умовно поділяються на три великі групи: словесні, наочні і практичні.

2. Метод проблемного навчання є яскравим прикладом словесних методів активізації пізнавальної діяльності здобувачів освіти: дає учням можливість міркувати, робити висновки, умовиводи. Виправданими є цікаві дискусії, доповіді та повідомлення на уроках іноземної мови. Важливо, щоб свої доповіді школярі не читали, а розповідали, вчилися говорити, міркувати, послідовно і логічно викладати свої думки.

3. При застосуванні наочних методів, учитель зазвичай керує роботою класу, а учні шляхом спостереження, вивчення обговорюють питання, вирішують поставлене завдання, роблять самостійні висновки зі спостереження. Схеми, таблиці й інший наочний матеріал повинен бути стандартним. Тут необхідно враховувати наочність, компактність - чітке і грамотне складання наочного робочого матеріалу, будь-то схема чи таблиця. Тобто, наочний метод активізації пізнавальної діяльності позбавляє від необхідності довгого викладу на словах, так і 
здобувачі освіти сприймають його краще, зважаючи також і на доступність такого методу навчання.

4. Інтерактив на уроках іноземної мови для вчителя - це найефективніший зворотний зв'язок, якісна інформація про те, як, що, на скільки розуміють учні пояснення педагога; можливість перевірити глибину сприймання, усвідомлення, обробки інформації, її «вбудову»у попередні знання, здатність оперувати нею. Можливість вільного спілкування із учителем, його поведінка під час дискусії, ставлення до школярів, вияви поваги (неповаги) до їхньої позиції, суджень $\epsilon$ вагомими факторами формування авторитету педагога у класі. Методика роботи з інтерактивними методами за участю вчителя створює позитивне підгрунтя для впровадження більш складних інтерактивних методів - методів, де спілкування відбувається вже між самими учнями, а педагог - тільки організуюча, спрямовуюча, коригуюча сила.

5. «Принципова еклектика», поєднуючи елементи різних підходів до навчання іноземної мови, передбачає використання всіх (або більшості) послідовностей уроків, які повинні містити три елементи: залучення, навчання й активізацію (Engage, Study та Activate). Ці три ESA елементи можуть зустрічатися в різному порядку / послідовності («прямі стрілки», «бумеранг» і «печворк»), залежно від основної теми уроку. 